\title{
ANALYSIS OF DROPOUT RATE AMONG FEMALE PRIMARY AND SECONDARY SCHOOLS: EVIDENCE FROM PUBLIC SCHOOLS IN SINDH PROVINCE
}

\author{
Ghazi Anwar Sultan \\ Research Scholar PhD Education, \\ Department of Education, Hamdard University Karachi \\ ghazianwar76@gmail.com \\ Muhammad Akhtar Kang \\ Assistant Professor, Faculty of Social Sciences \& Humanities, \\ Hamdard University, Karachi, Pakistan \\ dr.akhtar@hamdard.edu.pk
}

\begin{abstract}
The main purpose of this study was to investigate the factors and reasons behind the dropout of female students at primary and secondary level from public schools in Sindh. Samples of 120 senior teachers, 120 parents of dropped out students and 120students of primary and secondary public schools were selected systematically from schools of different districts of Sindh. Questionnaires were designed and data was collected and analyzed statistically through SPSS. Percentage and means were taken out. The major reasons found were cultural background, poverty, Lack of basic facilities, political and social norms, corporal punishment, socio economic conditions, lack of quality education, untrained teacher, loaded curriculum at different schools, learning environment and behavior of administration and parent's and unawareness. To reduce the dropout rate of female students at different levels; it is recommended that school administration, communities, local bodies and provincial government should work together to enhance the quality of education and must provide the basic facilities for students specially for female students at primary and secondary level in different public schools of Sindh to control the dropout rate. Until and unless all sections of society would not be ready to work for the betterment collectively, the positive change is impossible to come forth.
\end{abstract}

Keywords: Dropout Rate, Primary and Secondary School Levels, Public Schools of Sindh

\section{INTRODUCTION}

Sindh is the second largest province of Islamic Republic of Pakistan. It is a commercial Hub of Pakistan and Karachi, the first capital of Pakistan, is its capital. Its area is about 1,40,915 square kilometers. Its population is more than 40 million. 50\% are living in rural areas and rest are living in Urban areas. Beside Karachi, Hyderabad, Sukkur, Mirpurkhas, Tando Adam, Larkana, Nawabshah are its other important cities. It is basically an agrarian province based upon River Indus for its fertility. Contemporaneous of Ancient Egypt, Moen-jo-Daro, the 4500 years old civilization also lies here.Though it is an agricultural province, but textile, pottery, leather and carpets are the main products of this province. It has boundaries with India in the East and shares frontier lines with the Punjab in the North and with Baluchistan in the West. It has Arabian Sea in the South.

It has a rich history of the most advanced civilization of that time, and it was the center of peaceful livings even today the native speakers, of different languages spoken in Pakistan, live in Sindh.Sindh is called Bab ul Islam as in sub-continent Islam spread here by arrival of Muhammad Bin Qasim in 712 A.D.

During the past Somoros, Summans, Arghons,Talpurs, Mughals and then British ruled over Sindh. All left their marks on the land of Sindh. British laid here railways lines and divided the province in districts (Sindh.gov.pk).

Learning starts as a child takes breathe in this world. New things and ideas are learnt throughout the life. Education or learning is considered synonyms and it is defined as any effect on mind, ability, thoughts or on the character of a person. Simply it is said that transmission of 
knowledge, skills and values from one generation to another generation is called education. (Shekhar \& Chitra, 2014).

Importance of education cannot be ignored as it is the only key to progress in present scenario of the world. Without quality education no nation would think about progress and prosperity, but it is commonly observed that female education has more importance.

Female education is very important as they are the mothers of future and nation builders. They must be aware of next upcoming challenges across the globe. Unfortunately, Pakistan is one of those countries where gender discrimination is prominent. There are some cultural values in which people do not let daughters to go out after reaching adulthood and because of such values based upon gender discrimination, girls are not supposed to carry their studies still in this $21^{\text {st }}$ century. It would be a disaster for upcoming years when a major part of our population would not be educated, and it would be in their houses only to reproduce. Today women who are in houses; are not only housewives but they are house builders and caretakers too and how such an important person can be uneducated. Society must try to stop this dropout ratio among female students otherwise it would be proved a big disaster for whole nation in coming years. Reasons and hazards behind this problem must be discussed liberally and all factors of society must try together to resolve the issues behind this problem.

Not only government but NGOs can also work hard to reduce the dropout rate among female students at secondary level in Sindh. All sections of society should work for equality and gender discrimination should not be encouraged. Both males and females would have equal opportunities to prosper and to develop their abilities.

There are 30 districts in Sindh. People live in different districts, and they belong to different thoughts of life. There is caste system in Sindh and people belong to various casts and culture, so they are actually living in diverse situations in different districts. Some districts have all basic facilities, and some are still deprived of them such as shortage of drinking water, proper hospitals and wellknown educational institutes including schools and colleges etc. So, there can be different factors and reasons behind the drop out of female students in different areas. As rural areas are missing basic facilities, so they have some different sorts of reasons and facts behind the dropout of female students at primary and secondary level while at urban areas, where situation of basic facilities, is comparatively better, but they have their own issues.

The research has been started by the importance of education and being a Muslim, it is mandatory for every Muslim to be educated. Women are given very important role and dignity in Islam. Despite of gender discrimination, women are playing their role effectively for the progress of Pakistan but being a male dominated society they are always facing hazards in various fields of life as well as in education. (Irum, Bhatti, Munshi, 2015). According to a report of UNESCO the literacy rate of women in Pakistan is 36\% and if we compare with Sri Lanka who have $78 \%$ educated females, Pakistanis far behind from Sri Lanka, while India also have same problem with only $38 \%$ population of women is educated. At higher level in universities the percentage of women is only $2.5 \%$ (UNESCO 2014).

To bring a change in any one's life educational institutes play a key role as they help them to be successful in the world. Quality educational institutions are the founders of modern civil society and leaders to the path of progress and prosperity (Kramarae, 2000).

In less developed districts the number of schools and colleges are fewer, and girls are not sufficiently enrolled in them. With the reduction of number in enrolment, gender discrimination and deprivation for higher studies increase. Different cultural norms and values are there to stop females from higher education and thus they left far behind from the modern world (Batool, Sajid,\&Shaheen, 2013)

Sindh is a developing province of Pakistan. It has a rich cultural background. Education is the key factor behind any sort of success in life. This study would provide the way to eliminate gender discrimination for girls and would help to reduce the dropout rates of girls at primary and secondary level at Sindh. It would bring forth the reasons and factors that increase the dropout rate and by this study the recommendations would be presented by which dropout rates would be reduced.

This study would help different sectors of society to motivate and come ahead to solve the issue of girls' dropping rate from schools at both primary and secondary level. It would help the society to think positively about female education. Recommendations are for both government and 
parents to think about this issue. It would also suggest teachers to improve their teaching skills with efficiency so that students would engage themselves in educational process.

\section{Objectives}

- To analyze the dropout rate among females students at primary and secondary schools in Sindh.

- To determine the areas where after a little hard work ratio of enrolled girls can be increased in schools.

- To determine the role of media in this flaw of dropping out of girls.

- To cultivate the importance of female education in parents' minds.

- To eliminate the gender discrimination from the society.

\section{Research questions}

1. What are the root causes of dropping out the girls at primary level?

2. What are factors involved in dropping out of girls at secondary level?

3. What is the role of values of different ethical groups in dropping out of girls at primary and secondary level?

4. What is the role of gender discrimination in this regard?

5. How can rate of dropping out be reduced?

6. What initiatives should society and government have to take in order to stop or reduce the rate of dropping out of girls at primary and secondary level?

\section{Hypotheses}

1. There would be no discrimination among the opinions of male and female parents about dropping out rate of female students due to environment.

2. There would be no significant difference on the dropout issues between the opinion of male and female teachers.

3. There will be no difference among the opinion of different ages of female students about dropout due to cultural values.

4. There will be no difference in the opinion of parents on gender bases about dropping out their daughters due to poverty.

5. There is no difference in the opinion of teachers on experience bases about the dropout rate due to in appropriate behavior of teachers.

\section{REVIEW OF LITERATURE}

No one can claim progress and prosperity without education. Education is the only element that can change the whole climate of society. Societies cannot prosper without proper education. Getting education is primary right of each and every citizen. One cannot ignore the role of education in any aspect of life. If one wants to invest for future the best investment is on education. According to the World Bank report Pakistan is expending the least percent of its GDP over education in the region. In 2013, according to the report Bangladesh is spending 2.6, India 3.3, Indonesia 3.5, Iran 5.2, Malaysia 4.7, Nepal 4.2, Thailand 4.2 and Vietnam spent 5.3 percent of their total GDP while Pakistan spends only $2.1 \%$ which is the lowest in comparison(Source: World Bank, UNDP, UNESCO, FBS, Ministry of Education).

This indicates that Pakistan will have to focus on education so that it might make her ranking better at international level about education. Pakistan has lower literacy and enrolment rate while a higher dropout rate of students and different levels of education. Gender discrimination is there in education and quality at higher level is also debatable. Different indicators show that Pakistan is not properly investing on education and graph of schooling is going lower down. There can be many reasons behind this drawback, but the main reason is its division into segments; different systems of education have been running at the same time in same country. Various boards are working on their own grounds. Different institutions are working but not collaborating with each other (Hussain, 2005).

For making the situation better here in Pakistan, budget for education must be improved and spent properly. Different sectors of the society must be mobilized to raise the true literacy rate. New quality schools and colleges must be opened with all basic and advance facilities and to achieve success from this model. To achieve to international standards much more will have to be done beside 
the above mentioned efforts. The most important problem faced here in the region is the dropout rate at large scale. The drop ratio in 2003 was almost 50 percent for grade one (Tayyaba, 2014).

World Bank study proves that UPE (Universal Primary Education) should be the target of all countries, and this target would be achieved by improving school facilities and taking steps to reduce the number of students dropped out from schools at different levels of education. It is revealed in report that initially at pre-primary and primary stages a large number of children get admission in schools but gradually the number becomes reduced as the level goes higher. For instance, in a report from Africa, it is revealed that almost 38\% students were dropped out at primary level in 2005, and the ratio was better as in the year 2000 the dropout rate was more than $60 \%$ at primary level. In Congo only $51 \%$ children completed their primary education in 2007.

According to a report published in Bangladesh in the year 2000 the rate of primary students' completion has been $60 \%$ which was not good enough too. It means the most of students are quitting their education without being educated the basic skills. Beside other reasons, untrained teachers and unfriendly environment compel students to dropout (Alexander, 2008).

It is also a fact that gradually the numbers of enrolment in school have been increased, but at the same time the dropout rate has also been increased. Students are not going to complete their education cycle. Reasons and factors may have variation for them. The reasons might be poor health and economical condition. It might be lack of motivation towards schooling. Worst situation of houses can also be a main factor in dropout of students from different levels of education. Child labor and poverty can be a reason and main factor. Different areas have different values of life such as some areas still facing tribal culture so tribal culture can also play an important role in dropout ratio as they don't like students to be educated especially female students.

These problems were related to family and society, but teachers and schools' environment can also be responsible for this dropout. Lack of facilities, absentees of teachers or their misbehavior with students, their system of marking can also cause the dropout of students from schools. So, we cannot separate cultural and other related problems with Children in order to compel them to be dropped out from different levels of schools. Different students face different circumstances so no one can fix the factors of dropping out (Tayyaba, 2012).

Private schools are contributing high in the field of education in Pakistan. In all provinces they are increasing enrollment rate at secondary level. But they are still facing the problem of dropping out students. Even they try their level best or manage the situation via organizing and controlling but due to burden over students dropout rate is increasing there too (Fayyaz, 2007).

The main reason of dropout of the students can be the mismanagement of the heads of institutions as they are not able to meet the needs of people in order to get education. They were supposed to provide the best facilities to students by in the end they became failed and hence the dropout rate increases. Presentations of schools cannot be said adorable. Violence in educational institutes is another reason of dropout. By improving behavior, teachers can compel many students to come back to school (Dennis, 1998).

Some important reasons came forward are that teachers do not do justice in schools and thus students prefer to be dropped out. Beside that extensive physical punishment also make students to be dropped off. Poverty, illiterate parents, non-supportive environment for learning, child labor and tribal culture are also the reasons of dropping out of students at secondary level of schools. Trained teachers and regular contact with parents may reduce the rate of dropping out of students at secondary level. Communities can also play better role in this order, and they can increase enrollment and reduce dropping out rate. With the help of community co-curricular activities can increase the enrolment at secondary level. To reduce the dropout rate quality of education must be improved so that schools may have attraction for students and satisfaction for their parents. Management should arrange workshops for teachers and parents time to time so that teaching qualities should be enhanced and bonding with parents may go strong. Scholarship must be awarded to needy but deserving students so that they cannot be dropped out because of poor financial condition of their families. (Samiullah \& Tahira, 2018).

\section{RESEARCH METHODOLOGY}

As a quantitative and descriptive research by nature three questionnaires were used to get data from the respondents. Descriptive research is a type of quantitative research which is used to describe the 
educational phenomena carefully (Sami \& Tahira, 2018). All public schools of Sindh were the population of this study and as population was so big so that purposive random sampling technique was used to collect data from different districts of Sindh. The questionnaires were given to the selected dropped out students, teachers and parents of the dropped-out students. There are 30 districts in Sindh so overall 4 respondents were selected from each district and thus 120 respondents were there to reply from each category. Total 360 respondents filled the questionnaire i.e., 120 students, 120 teachers, and 120 parents. Five options were given to each respondent for each item which were, Strongly Disagree, Disagree, Undecided, Agree, Strongly Agree.

Overall, three questionnaires were designed and delivered to the selected respondents from students, teachers and parents. All three questionnaires were developed by the researcher under the supervision of the supervisor in the light of the objectives of the study, research questions and hypothesis.

In order to ensure the quality of the research questionnaire were personally delivered and collected by the researcher so that 100 percent rate would be achieved.

\section{DATA ANALYSIS}

There were total 60 items and their validity and reliability were tested though SPSS and when their Reliability Analysis showed alpha's value .822 then supervisor let the researchers to work ahead. All items were in the form of statements and were tested through Chi-Square tests. Hypotheses were tested through Independent T Test and One-Way ANOVA. In this articles researcher represented 3 items' testing as a sample (one from each group to show how the other items were tested). Other items were tested in the same manner. After testing items and hypotheses, the conclusions were given to prove or reject the null or alternate hypotheses.

Testing of Item 1 From Teachers' Questionnaire On Chi-Square Test.

Table No. 1 Abusive use of cell phones makes students away from studies so they prefer to be dropped out.

\section{TABLE 1}

Abusive use of cell phones makes students away from studies, so they prefer to be dropped out.

\begin{tabular}{|c|c|c|c|c|}
\hline \multicolumn{5}{|c|}{ Descriptive Statistics } \\
\hline $\mathrm{N}$ & Mean & Std. Deviation & Minimum & Maximum \\
\hline 120 & 3.49 & 1.402 & 1 & 5 \\
\hline & & Observed N & Expected N & Residual \\
\hline Strongly D & & 12 & 24.0 & -12.0 \\
\hline Disagree & & 30 & 24.0 & 6.0 \\
\hline Undecided & & 1 & 24.0 & -23.0 \\
\hline Agree & & 41 & 24.0 & 17.0 \\
\hline Strongly A & & 36 & 24.0 & 12.0 \\
\hline Total & & 120 & & \\
\hline \multicolumn{5}{|c|}{ Test Statistics } \\
\hline \multicolumn{2}{|l|}{ Chi-Square } & \multicolumn{3}{|c|}{$47.583^{\mathrm{a}}$} \\
\hline \multicolumn{2}{|c|}{\begin{tabular}{|l|} 
Df \\
\end{tabular}} & \multicolumn{3}{|c|}{4} \\
\hline \multicolumn{2}{|c|}{$\begin{array}{l}\text { Asymp. Sig. } \\
\end{array}$} & \multicolumn{3}{|c|}{.000} \\
\hline
\end{tabular}

Table 1 shows that $(n=12)$ out of 120 i.e. $10 \%$ teachers Strongly Disagreed, $(n=30)$ out of 120 i.e. $25 \%$ teachers disagreed, $(n=1)$ out of 120 i.e. $0.83 \%$ teachers undecided, $(n=41)$ out of 120 i.e. $34.16 \%$ teachers Agreed and $(n=36)$ out of 120 i.e. $30 \%$ teachers Strongly Agreed to the statement that Abusive use of cell phones makes students away from studies so they prefer to be dropped out. Conclusion: abusive use of cell phones makes students away from studies, so they prefer to be dropped out. 
Testing Of Item 1 From Parents' Questionnaire On Chi-Square Test.

Table No. 2

Financial conditions compel parents to dropout their children especially girls from schools.

\begin{tabular}{|c|c|c|c|c|}
\hline $\mathrm{N}$ & Mean & Std. Deviation & Minimum & Maximum \\
\hline \multirow[t]{2}{*}{120} & 3.11 & 1.269 & 1 & 5 \\
\hline & \multicolumn{2}{|c|}{ Observed N } & Expected N & Residual \\
\hline Strongly Disagree & \multicolumn{2}{|c|}{12} & 24.0 & -12.0 \\
\hline Disagree & \multicolumn{2}{|c|}{41} & 24.0 & 17.0 \\
\hline Undecided & \multicolumn{2}{|c|}{2} & 24.0 & -22.0 \\
\hline Agree & \multicolumn{2}{|c|}{52} & 24.0 & 28.0 \\
\hline Strongly Agree & \multicolumn{2}{|c|}{13} & 24.0 & -11.0 \\
\hline Total & \multicolumn{2}{|c|}{120} & & \\
\hline \multicolumn{5}{|c|}{ Test Statistics } \\
\hline Chi-Square & \multicolumn{4}{|c|}{$75.917^{\mathrm{a}}$} \\
\hline Df & \multicolumn{4}{|c|}{4} \\
\hline Asymp. Sig. & \multicolumn{4}{|c|}{.000} \\
\hline
\end{tabular}

Table 2 shows that $(n=12)$ out of 120 i.e. $10 \%$ teachers Strongly Disagreed, $(n=41)$ out of 120 i.e. $34.16 \%$ teachers disagreed, $(n=2)$ out of 120 i.e. $1.66 \%$ teachers undecided, $(n=52)$ out of 120 i.e. $43.33 \%$ teachers Agreed and $(n=13)$ out of 120 i.e. $10.83 \%$ teachers Strongly Agreed to the statement that financial conditions compel parents to dropout their children especially girls from schools.Conclusion: Financial conditions compel parents to dropout their children especially girls from schools.

Testing Of Item 1 from Students' Questionnaire on Chi-Square Test

Table No. 3

Dropping out from schools may have worst impacts on students' upcoming lives.

\begin{tabular}{|c|c|c|c|c|}
\hline \multicolumn{5}{|c|}{$\mid$\begin{tabular}{l|l|l|l|} 
& &
\end{tabular}} \\
\hline $\mathrm{N}$ & Mean & Std. Deviation & Minimum & Maximum \\
\hline 120 & 3.22 & 1.456 & 1 & 5 \\
\hline \multirow{2}{*}{\multicolumn{2}{|c|}{ Strongly Disagree }} & Observed N & Expected N & Residual \\
\hline & & 17 & 24.0 & -7.0 \\
\hline \multicolumn{2}{|l|}{ Disagree } & 35 & 24.0 & 11.0 \\
\hline \multicolumn{2}{|l|}{ Undecided } & 3 & 24.0 & -21.0 \\
\hline \multicolumn{2}{|l|}{ Agree } & 35 & 24.0 & 11.0 \\
\hline \multicolumn{2}{|l|}{ Strongly Agree } & 30 & 24.0 & 6.0 \\
\hline \multicolumn{2}{|l|}{ Total } & 120 & & \\
\hline \multicolumn{5}{|c|}{ Test Statistics } \\
\hline \multicolumn{2}{|l|}{ Chi-Square } & \multicolumn{2}{|c|}{$32.000^{\mathrm{a}}$} & \\
\hline \multicolumn{2}{|l|}{ Df } & \multicolumn{2}{|c|}{4} & \\
\hline \multicolumn{5}{|c|}{\begin{tabular}{|l|l|} 
Asymp. Sig. & \\
\end{tabular}} \\
\hline
\end{tabular}

Table 4.3.1.3 shows that $(n=17)$ out of 120 i.e. $14.16 \%$ teachers Strongly Disagreed, $(n=35)$ out of 120 i.e. $29.16 \%$ teachers disagreed, $(n=3)$ out of 120 i.e. $2.5 \%$ teachers undecided, $(n=35)$ out of 120 i.e. $29.16 \%$ teachers Agreed and $(n=30)$ out of 120 i.e. $25 \%$ teachers Strongly Agreed to the 
statement that Dropping out from schools may have worst impacts on students' upcoming lives. Conclusion: Dropping out from schools may have worst impacts on students' upcoming lives.

\section{Testing Of Hypothesis}

There were five hypotheses, and they were checked by T-Test and One-Way ANOVA Test.

\section{Hypothesis 1}

$\mathrm{H}_{0} \quad$ There would be no discrimination among the opinions of male and female parents about dropping out rate of female students due to environment.

$\mathrm{H}_{1} \quad$ There would be discrimination among the opinions of male and female parents about dropping out rate of female students due to environment

\section{TABLE 4}

\begin{tabular}{|c|c|c|c|c|c|c|c|c|c|c|c|}
\hline \multicolumn{12}{|c|}{ Group Statistics } \\
\hline & Sex & \multicolumn{2}{|c|}{$\mathrm{N}$} & \multicolumn{3}{|c|}{ Mean } & \multicolumn{2}{|c|}{ Std. Deviation } & \multicolumn{3}{|c|}{ Std. Error Mean } \\
\hline \multirow[t]{2}{*}{ Environment } & Male & \multicolumn{2}{|c|}{101} & \multirow{2}{*}{\multicolumn{3}{|c|}{$\begin{array}{l}2.93 \\
2.62\end{array}$}} & \multicolumn{2}{|l|}{.782} & \multicolumn{3}{|c|}{.078} \\
\hline & Female & \multicolumn{2}{|c|}{19} & & & & \multicolumn{2}{|l|}{.848} & \multicolumn{3}{|c|}{.195} \\
\hline \multicolumn{12}{|c|}{ Independent Samples Test } \\
\hline & & \multicolumn{2}{|c|}{$\begin{array}{l}\text { Levine's Test } \\
\text { for Equality of } \\
\text { Variances }\end{array}$} & \multicolumn{8}{|c|}{ T-test for Equality of Means } \\
\hline & & \multirow[b]{2}{*}{$\mathrm{F}$} & \multirow[b]{2}{*}{ Sig. } & \multirow[b]{2}{*}{$\mathrm{T}$} & \multirow[b]{2}{*}{$\mathrm{df}$} & \multirow{2}{*}{$\begin{array}{l}\text { Sig. } \\
(2- \\
\text { tailed })\end{array}$} & \multirow{2}{*}{$\begin{array}{c}\text { Mean } \\
\text { Differen } \\
\text { ce }\end{array}$} & \multirow{2}{*}{\multicolumn{2}{|c|}{$\begin{array}{c}\text { Std. Error } \\
\text { Differenc } \\
\mathrm{e}\end{array}$}} & \multicolumn{2}{|c|}{$\begin{array}{c}95 \% \\
\text { Confidence } \\
\text { Interval of the } \\
\text { Difference }\end{array}$} \\
\hline & & & & & & & & & & Lower & $\begin{array}{c}\text { Uppe } \\
\text { r }\end{array}$ \\
\hline \multirow[t]{2}{*}{ Environment } & \begin{tabular}{|l} 
Equal \\
variances \\
assumed
\end{tabular} & .004 & .952 & $\begin{array}{c}1.56 \\
2\end{array}$ & 118 & .121 & .310 & .1 & & -.083 & .702 \\
\hline & \begin{tabular}{|l} 
Equal \\
variances \\
not \\
assumed
\end{tabular} & & & $\begin{array}{c}1.47 \\
7\end{array}$ & $\begin{array}{c}24.10 \\
5\end{array}$ & .153 & .310 & .2 & & -.123 & .742 \\
\hline
\end{tabular}

Conclusion: In statistical results of Independent T Test, if the significant value were less than 0.05 , the hypothesis would have been rejected but in this case the significant value is 0.952 which clearly indicates towards the acceptance of the hypothesis which means there is clearly no difference in the opinion of male and female parents about dropping out rate of female students due to environment.

\section{Hypothesis 2}

$\mathrm{H}_{0} \quad$ There would be no significant difference on the dropout issues among the opinion of male and female teachers.

$\mathrm{H}_{1} \quad$ There would be a significant difference on the dropout issues among the opinion of male and female teachers.

\section{TABLE 5}

\begin{tabular}{|c|c|c|c|c|c|}
\hline \multicolumn{7}{|c|}{ Group Statistics } \\
\hline \multirow{2}{*}{ Dropout } & Sex & N & Mean & Std. Deviation & Std. Error Mean \\
\cline { 2 - 6 } & Male & 69 & 2.93 & .685 & .082 \\
\cline { 2 - 6 } & Female & 51 & 3.03 & .628 & .088 \\
\hline
\end{tabular}




\begin{tabular}{|c|c|c|c|c|c|c|c|c|c|c|}
\hline \multicolumn{11}{|c|}{ Independent Samples Test } \\
\hline & & \multicolumn{2}{|c|}{$\begin{array}{l}\text { Levene's Test } \\
\text { for Equality of } \\
\text { Variances }\end{array}$} & \multicolumn{7}{|c|}{ t-test for Equality of Means } \\
\hline & & \multirow[b]{2}{*}{$\mathrm{F}$} & \multirow[b]{2}{*}{ Sig. } & \multirow[b]{2}{*}{$\mathrm{T}$} & \multirow[b]{2}{*}{ df } & \multirow[b]{2}{*}{$\begin{array}{l}\text { Sig. (2- } \\
\text { tailed) }\end{array}$} & \multirow[b]{2}{*}{$\begin{array}{c}\text { Mean } \\
\text { Differen } \\
\text { ce }\end{array}$} & \multirow[b]{2}{*}{$\begin{array}{l}\text { Std. Error } \\
\text { Differenc } \\
\mathrm{e}\end{array}$} & \multicolumn{2}{|c|}{$\begin{array}{c}95 \% \\
\text { Confidence } \\
\text { Interval of the } \\
\text { Difference }\end{array}$} \\
\hline & & & & & & & & & Lower & $\begin{array}{c}\text { Uppe } \\
\mathrm{r}\end{array}$ \\
\hline \multirow[t]{2}{*}{ Dropout } & \begin{tabular}{|l} 
Equal \\
variances \\
assumed
\end{tabular} & .963 & .328 & -.754 & 118 & .452 & -.092 & .122 & -.334 & .150 \\
\hline & $\begin{array}{l}\text { Equal } \\
\text { variances } \\
\text { not } \\
\text { assumed }\end{array}$ & & & -.764 & $\begin{array}{l}112 . \\
556\end{array}$ & .447 & -.092 & .121 & -.331 & .147 \\
\hline
\end{tabular}

Conclusion: In statistical results of Independent T Test, if the significant value were less than 0.05 , the hypothesis would have been rejected but in this case the significant value is 0.328 which clearly indicates towards the acceptance of the hypothesis which means there is clearly no significant difference on the dropout issues between the opinion of male and female teachers.

\section{Hypothesis 3}

$\mathrm{H}_{\mathrm{o}} \quad$ There will be no significant difference among the opinion of different ages of male and female students about dropout rate due to cultural values.

$\mathrm{H}_{1} \quad$ There will be a significant difference among the opinion of different ages of male and female students about dropout rate due to cultural values.

\section{TABLE 6}

\begin{tabular}{|c|c|c|c|c|c|c|c|c|c|c|}
\hline \multicolumn{11}{|c|}{ Group Statistics } \\
\hline & Sex & \multicolumn{3}{|c|}{$\mathrm{N}$} & \multicolumn{3}{|c|}{ Mean } & Std. Deviation & \multicolumn{2}{|c|}{ Std. Error Mean } \\
\hline \multirow[t]{2}{*}{ Dropout } & Male & \multicolumn{3}{|c|}{69} & \multicolumn{2}{|r|}{2.93} & & .685 & \multicolumn{2}{|c|}{.082} \\
\hline & Female & \multicolumn{2}{|r|}{51} & & \multicolumn{2}{|r|}{3.03} & \multicolumn{2}{|r|}{.628} & \multicolumn{2}{|c|}{.088} \\
\hline \multicolumn{11}{|c|}{ Independent Samples Test } \\
\hline & & \multicolumn{2}{|c|}{$\begin{array}{c}\text { Levene's Test } \\
\text { for Equality } \\
\text { of Variances }\end{array}$} & \multicolumn{7}{|c|}{ t-test for Equality of Means } \\
\hline & & \multirow[t]{2}{*}{$\mathrm{F}$} & \multirow[t]{2}{*}{ Sig. } & \multirow[t]{2}{*}{$\mathrm{t}$} & \multirow[t]{2}{*}{ df } & \multirow[t]{2}{*}{$\begin{array}{l}\text { Sig. (2- } \\
\text { tailed) }\end{array}$} & \multirow[t]{2}{*}{\begin{tabular}{|l} 
Mean \\
Differenc \\
$\mathrm{e}$
\end{tabular}} & \multirow{2}{*}{$\begin{array}{l}\text { Std. } \\
\text { Error } \\
\text { Differenc } \\
\text { e }\end{array}$} & \multicolumn{2}{|c|}{$\begin{array}{l}\text { 95\% Confidence } \\
\text { Interval of the } \\
\text { Difference }\end{array}$} \\
\hline & & & & & & & & & Lower & Upper \\
\hline \multirow[t]{2}{*}{ Dropout } & $\begin{array}{c}\text { Equal } \\
\text { variance } \\
\mathrm{s} \\
\text { assumed }\end{array}$ & .963 & .328 & -.754 & 118 & .452 & -.092 & .122 & -.334 & .150 \\
\hline & $\begin{array}{c}\text { Equal } \\
\text { variance } \\
\text { s not } \\
\text { assumed }\end{array}$ & & & -.764 & 112. & .447 & -.092 & .121 & -.331 & .147 \\
\hline
\end{tabular}

Conclusion: In statistical results of Independent T Test, if the significant value were less than 0.05 , the hypothesis would have been rejected but in this case the significant value is 0.328 which clearly 
indicates towards the acceptance of the hypothesis which means there is clearly no significant difference on the dropout issues between the opinion of male and female teachers.

\section{Hypothesis 4}

$\mathrm{H}_{0} \quad$ There will be no significant difference in the opinion of parents on gender basis about dropping out their daughters due to poverty.

$\mathrm{H}_{1} \quad$ There will be a significant difference in the opinion of parents on gender basis about dropping out their daughters due to poverty.

\section{TABLE 7}

\begin{tabular}{|c|c|c|c|c|c|}
\hline \multicolumn{5}{|c|}{ Group Statistics } \\
\hline \multirow{2}{*}{ Poverty } & Sex & $\mathrm{N}$ & Mean & Std. Deviation & Std. Error Mean \\
\cline { 2 - 6 } & Male & 101 & 3.02 & .719 & .072 \\
\cline { 2 - 6 } & Female & 19 & 2.68 & .728 & .167 \\
\hline
\end{tabular}

\begin{tabular}{|c|c|c|c|c|c|c|c|c|c|c|}
\hline \multicolumn{11}{|c|}{ Independent Samples Test } \\
\hline & & \multicolumn{2}{|c|}{$\begin{array}{c}\text { Levene's Test for } \\
\text { Equality of } \\
\text { Variances }\end{array}$} & \multicolumn{7}{|c|}{ t-test for Equality of Means } \\
\hline & & \multirow[b]{2}{*}{$\mathrm{F}$} & \multirow[b]{2}{*}{ Sig. } & \multirow[b]{2}{*}{$\mathrm{t}$} & \multirow[b]{2}{*}{ df } & \multirow[b]{2}{*}{$\begin{array}{l}\text { Sig. (2- } \\
\text { tailed) }\end{array}$} & \multirow{2}{*}{$\begin{array}{l}\text { Mean } \\
\text { Differen } \\
\text { ce }\end{array}$} & \multirow{2}{*}{$\begin{array}{l}\text { Std. } \\
\text { Error } \\
\text { Differe } \\
\text { nce }\end{array}$} & \multicolumn{2}{|c|}{$\begin{array}{c}95 \% \\
\text { Confidence } \\
\text { Interval of the } \\
\text { Difference }\end{array}$} \\
\hline & & & & & & & & & Lower & $\begin{array}{l}\text { Uppe } \\
\mathrm{r}\end{array}$ \\
\hline \multirow[t]{2}{*}{ Poverty } & $\begin{array}{l}\text { Equal } \\
\text { variances } \\
\text { assumed }\end{array}$ & .017 & .897 & 1.862 & 118 & .065 & .336 & .180 & -.021 & .692 \\
\hline & $\begin{array}{l}\text { Equal } \\
\text { variances } \\
\text { not } \\
\text { assumed }\end{array}$ & & & 1.846 & $\begin{array}{c}25.05 \\
8\end{array}$ & .077 & .336 & .182 & -.039 & .710 \\
\hline
\end{tabular}

Conclusion: In statistical results of Independent T Test, if the significant value were less than 0.05 , the hypothesis would have been rejected but in this case the significant value is 0.897 which clearly indicates towards the acceptance of the hypothesis which means there is clearly no significant difference in the opinion of parents on gender basis about dropping out their daughters due to poverty.

\section{Hypothesis 5}

$\mathrm{H}_{0} \quad$ There is no significant difference in the opinion of teachers on experience basis about the dropout rate due to in appropriate behavior of teachers.

$\mathrm{H}_{1} \quad$ There is a significant difference in the opinion of teachers on experience basis about the dropout rate due to in appropriate behavior of teachers.

\section{TABLE 8}

\begin{tabular}{|l|c|c|c|c|c|}
\hline \multicolumn{7}{|c|}{ ANOVA } \\
\hline Environment & $\begin{array}{c}\text { Sum of } \\
\text { Squares }\end{array}$ & Df & Mean Square & F & Sig. \\
\hline Between Groups & 1.606 & 4 & .402 & .588 & .672 \\
\hline Within Groups & 78.473 & 115 & .682 & & \\
\hline Total & 80.079 & 119 & & & \\
\hline
\end{tabular}


Conclusion: In ONE-WAY ANOVA Test if the significant value were less than 0.05, the hypothesis would have been rejected but in this case the significant value is 0.672 which clearly indicates the acceptance of the hypothesis which means that There is no significant difference in the opinion of teachers on experience basis about the dropout rate due to inappropriate behavior of teachers.

\section{FINDINGS}

Through responses the research found many reasons such as poverty, distance from schools, cultural background in some areas, family behavior in some cases, adulthood of females and teachers ways of teaching and behavior in classroom also play a big role in dropping out of female students at secondary level. But the main findings of the research are.

- There is no difference in the opinion of male and female parents about dropping out rate of female students due to environment

- There is no significant difference on the dropout issues between the opinion of male and female teachers.

- The re is no significant difference on the dropout issues between the opinion of male and female teachers.

- There is no significant difference in the opinion of parents on gender basis about dropping out their daughters due to poverty

- There is no significant difference in the opinion of teachers on experience basis about the dropout rate due to inappropriate behavior of teachers.

\section{RECOMMENDATIONS}

1) Schools should have basic facilities and learning environment within a boundary wall to produce a healthy competition among students.

2) Government and school administration should mobilize different community heads in order to increase enrolment of female students and decrease the dropout rate.

3) Technical courses and house crafts making should be started in schools so that girls can make resource of income to their families and poverty can be reduced.

4) Untrained teachers should not be appointed, and proper check and balance system is necessary in schools to bring improvement.

5) Government is providing free books but now copies and other stationary is also needed to carry them education.

6) Abusive use of mobile phones must be restricted by parents and teachers.

7) Public Private Partnership as SEF (Sindh Education Foundation) is necessary in province, and it must be extended.

8) Media should play an important role to aware parents about female education and dramas and serial should enhance positive impacts of education on females' lives.

9) Parents should play their role which is very important. They have to keep an eye on the activities of their kids and motivate them to take interest in studies.

10) Time is changing so old and tradition thoughts must be changed about not sending daughters to schools and for this government can subsidize parents and present constitutional amendments to compel parents for sending their daughters to schools.

\section{REFERENCES}

Alexander, R. (2008). 'Education for All, the Quality Imperative and the Problem of Pedagogy, CREATE Pathways to Access No 20. Consortium for Research on Educational Access, Transitions and Equity: University of Sussex

Batool, S.Q., Sajid, M.A., \& Shaheen, I. (2013). Gender and Higher Education in Pakistan. International Journal of Gender and Women's Studies 1(1);15-28

Bhatti, L. R. (2007). Causes of primary school dropout from Tehsil Lahore andShariqpur. Unpublished Master thesis: University of the Punjab.

Farooq, S. M. (2014). Causes of Primary School Students' Dropout in Punjab Primary School Teachers' Perspective .Journal of Elementary Education, 26(1);57-79. 
Fayyaz, N. (2007). Impact of Management system of Agha Khan Education service on women development in Gilgit. (M.Phil), AIOU, Islamabad.

Hussain, I. (2005). Education, employment and economic development in Pakistan. Inaugural Address delivered at the Conference on Education held at WoodrowWilson Center, Washington D.C. on April 15.

Hussain, I. (2005). Inaugural Address delivered at the Conference on Education held at Woodrow Wilson Center, Washington D.C. on April 15, 2005. News articles Available at: http://www.studysols.com/pakistan-literacy-rate

Irum, S., Bhatti, T., \& Munshi, P. (2015). The Sindh University.Journal of Education 44(1); 173 191

Kramarae, P., Cheris, M., \& Dale, D. (2000). Routledge International Encyclopedia of Women, Volt. Routledge. New York. USA. pp. 211-219.

Malik, Z. M. (2000). Causes of dropout in primary school: A study of primary school dropout in Sargodha Tehsil during 1996-97 to 1997-98. Pakistan Journal ofapplied Sciences, 2(6), 646648.

Ministry of Education. (2003). National plan of action on Education for All 2001-2015. Islamabad: Govt. of Pakistan.

Samiullah, \& Bibi, T. (2018), "Factors Affecting Dropout Rate at Secondary School Level in Private Schools of Punjab, Pakistan International Journal of Management Sciences and Business Research, April-2018 ISSN (2226-8235) Vol-7, Issue 4

Shami, P. A., \&Hussain, K. S. (2005). Basic education in Pakistan. Islamabad:Academy of Educational Planning and Management.

Shekhar, K.J., \& Chitra, S. (2014). Educational Problems, P.1, Pacific Books International, New Delhi India.

Tayyaba, Z. (2012). Reasons of high dropout rate of students in Grade 5-6at public schools of district Kashmore (Sindh-Pakistan) in 2010-11. Journal of Research and Reflections in Education (JRRE), 6(2), 145-153.

Tayyaba, Z. (2014). Probing reasons of High School dropout rate in Grade 5-6 at district Thatta, Sindh Pakistan, Asian Journal of Social Sciences \& Humanities, 3(1) February 2014

Zeba, A. S., Haque, M., Faizunnissa, A., \& Sultana, M. (2002). Adolescents and Youth in Pakistan 2001-2002: A nationally representative survey. Islamabad: UNICEF. 